\title{
PERLINDUNGAN HUKUM TERHADAP NOTARIS DAN PPAT SEBAGAI PIHAK PELAPOR DALAM TINDAK PIDANA PENCUCIAN UANG
}

\author{
Daniella Herera Yosifany Hutagalung \\ Fakultas Hukum, Universitas Brawijaya \\ J1. MT. Haryono 169 Malang \\ Email: jurnalmicha@gmail.com
}

\begin{abstract}
Abstrak
Tujuan penelitian ini adalah: Pertama, untuk menganalisis rasio legis ketentuan Pasal 3 Peraturan Pemerintah Nomor 43 Tahun 2015 terkait pelaporan indikasi tindak pidana pencucian uang yang berhubungan dengan rahasia jabatan Notaris. Kedua, ratio legis Pasal 16 ayat (1) huruf F Undang-Undang Jabatan Notaris terkait wewajiban Notaris/ PPAT merahasiakan akta dengan pengecualian. Ketiga, perlindungan hukum terhadap Notaris/PPAT sebagai pihak pelapor yang mengindikasi adanya tindak pidana pencucian uang. Metode penelitian yang digunakan adalah penelitian hukum dengan jenis penelitian normatif. Berdasarkan hasil penelitian, rasio legis pengaturan Notaris dan PPAT tidak disertai dengan ketentuan perlindungan hukum sebagai pihak pelapor dalam tindak pidana pencucian uang dirasa dirasa kurang tepat, karena demi menjamin perlindungan hukum bagi pihak pelapor maka diperlukan kepastian hukum demi menjaga keamanan dan kelancaran ketika menyampaikan pelaporan, pun juga demikian dengan Peraturan Pemerintah Nomor 43 Tahun 2015 tentang Pihak Pelapor dalam Pencegahan dan Pemberantasan Tindak Pidana Pencucian Uang Jo Permenkumham Nomor 9 Tahun 2017 tentang Penerapan prinsip mengenali pengguna jasa bagi Notaris, bahwa sesungguhnya Notaris tidak berkewajiban untuk menggali kebenaran materiil kepada para pengguna jasa, namun yang berwenang untuk hal tersebut adalah hakim di pengadilan. Upaya perlindungan hukum bagi Notaris oleh Majelis Kehormatan Notaris berupa pengawasan dan pemberian sanksi serta sebagai gerda depan Notaris ketika berurusan dengan pihak berwenang baik kepolisian maupun kejaksaan, Notaris tidak dapat sewenang wenang dipanggil oleh penyidik karena penyidik harus melalui beberapa tahapan untuk menghadirkan Notaris sebagai saksi untuk dimintai keterangan, adapun prosedur yang wajib dilakukan oleh pihak berwenang dengan cara mengirimkan surat permohonan pemanggilan Notaris kepada Majelis Kehormatan Notaris.
\end{abstract}

\section{Kata Kunci: Notaris; Pejabat Pembuat Akta Tanah; PencucianUang; Perlindungan- Hukum}

\begin{abstract}
The objectives of this study are: First, to analyze the legis ratios of the provisions of Article 3 of Government Regulation Number 43 of 2015 related to reporting indications of money laundering crimes relating to confidential Notary positions. Second, the legis ratio Article 16 paragraph (1) letter F of the Notary Position Law related to the notary obligation I PPAT to keep the deed with an exception. Third, legal protection of Notary / PPAT as the reporting party that indicates the existence of a money laundering crime. The research method used is legal research with normative research. Based on the results of the study, the legal ratio of Notar y and PPAT regulation is not accompanied by provisions for legal protection as a reporting party in the crime of money laundering deemed inappropriate, because in order to guarantee legal protection for the reporting party, legal certainty is needed to maintain security and smoothness when submitting reporting, Likewise, Government Regulation Number 43 of 2015 concerning Reporting Parties in the Prevention and Eradication of Money Laundering Jo Permenkumham Number 9 of 2017 concerning the Application of the principle of recognizing service users for Notaries, that in fact the Notary is not obliged to explore material truths to service users, but the authority for this is the judge in court. Legal protection efforts for Notaries by the Notary Honorary Council
\end{abstract}


in the form of supervision and sanction as well as the front of the Notary when dealing with the authorities both the police and the prosecutor's office, the Notary Public cannot be arbitrarily summoned by the investigator because the investigator must go through several stages to present the Notary Public as a witness to be asked for information, as for the procedures that must be carried out by the authorities by sending a letter requesting a Notary to the Notary Honorary Council.

\section{Keywords: Land Deed Office; Legal Protection; Money Laundering; Notary}

\section{A. PENDAHULUAN}

Notaris dan Pejabat Pembuat Akta Tanah (PPAT) dalam membuat akta otentik hanya memformulasikan hubungan hukum antara para pihak dalam bentuk tertulis dalam suatu format tertentu dalam akta otentik serta wajib menerapkan prinsip kehati-hatian dan menerapkan prinsip mengenal nasabah dalam ketikan akan menggunakan jasanya, karena saat Notaris/ PPAT membuat akta autentik maka Notaris/PPAT membutuhkan kepastian hukum yang berupa data-data yang diberikan oleh kliennya. ${ }^{1}$

Notaris termasuk salah satu profesi yang dikenakan wajib lapor ke Pusat Pelaporan dan Analisis Transaksi Keuangan (PPATK) jika menemukan transaksi. keuangan mencurigakan. Kewajiban ini tercantum dalam Peraturan Pemerintah (PP) No. 43 Tahun 2015 tentang Pihak Pelapor dalam Pencegahan dan Pemberantasan Tindak Pidana Pencucian Uang. Dalam menjalankan tugasnya sebagai pejabat umum, notaris dinilai bisa dimanfaatkan untuk menyembunyikan atau menyamarkan hasil tindak pidana pencucian uang.

Pasal 16 ayat (1) huruf f UU No. 30 Tahun 2004 sebagaimana diubah dengan UU No. 2 Tahun 2014 tentang Jabatan Notaris (UUJN) telah menegaskan "Notaris wajib merahasiakan segala sesuatu mengenai Akta yang dibuatnya dan segala keterangan yang diperoleh guna pembuatan Akta sesuai dengan sumpah/janji jabatan, kecuali undang-undang menentukan lain”. Sehingga dari hal tersebut telah memberi pesan bahwa setiap Notaris harus merahasiakan prodak hukum yang dibuatnya berupa akta.

Susdiarto menjelaskan jabatan Notaris didasarkan kepercayaan antara notaris dan pihak yang menggunakan jasanya. Karenanya, ia hanya dapat memberikan, memperlihatkan, atau memberitahukan isi akta, grosse akta, minuta akta, salinan akta/kutipan akta kepada orang yang berkepentingan langsung. Keistimewaan itu diatur dalam Pasal 1909 ayat (3) KUHPerdata dan Pasal 322 KUHP. Karena itu, setiap notaris wajib merahasiakan isi akta dan keterangan yang diperoleh dalam pembuatan akta notaris, kecuali diperintahkan Undang-Undang. Disebutkan dalam Pasal 66 ayat (1) KUHP yakni "Untuk kepentingan penyidik, penuntut umum, atau hakim dengan persetujuan Majelis Pengawas Daerah berwenang:

a. Mengambil fotokopi Minuta Akta dan atau surat-surat yang dilekatkan pada Minuta Akta atau Protokol Notaris dalam penyimpanan Notaris.

b. Memanggil Notaris untuk hadir dalam pemeriksaan yang berkaitan dengan akta yang dibuatnya atau Protokol Notaris yang berada dalam penyimpanan Notaris."

Oleh karena itu kewajiban senada tertuang dalam sumpah jabatan seorang notaris, sebagaimana disebut dalam Pasal 4 Undang-Undang Jabatan Notaris: "bahwa saya akan merahasiakan isi akta dan keterangan yang diperoleh dalam pelaksanaan jabatan saya". Pelanggar terhadap sumpah jabatan itu justru bisa berbuah ancaman 9 bulan penjara, sebagaimana disebut Pasal 332 KUHP. PP No. 43 Tahun 2015 dan Peraturan Kepala PPATK (Pusat Pelaporan dan Analisis Keuangan) Nomor 11 Tahun 2016 tidak memberikan patokan yang jelas dan aman bagi Notaris terkait transaksi keuangan mencurigakan prosedur seperti

${ }^{1}$ Tan Thong Kie.(2000). Studi Serba Serbi Praktek Notaris. Jakarta: IchtiarBaru Van Hoeve, hlm. 159 
apa yang harus membuat notaris melapor ke PPATK. Padahal ini berkaitan dengan besaran nilai transaksi serta ukuran transaksi yang mencurigakan.

Permasalahan di atas tentu tidak terlepas dengan beberapa peraturan perundangundangan lainnya yang mengantur tentang perlindungan terhadap pihak Pelapor yang melaporkan adanya dugaan tindak pidana pencucian uang. Peraturan Perundang-undangan yang mengatur mengenai perlindungan hukum terhadap pihak yang melaporkan adanya tindak pidana adalah Undang-undang Nomor 31 Tahun 2014 Tentang Perubahan Atas UndangUndang Nomor 13 Tahun 2006 Tentang Perlindungan Saksi Dan Korban (Selanjutnya ditulis UU Perlindungan Saksi dan Korban).

Namun Undang-Undang tersebut tidak menjelaskan prosedur tata cara, aturan teknis dan tidak memberikan penjelasan lebih jelas terkait sejauh mana Notaris/PPAT sebagai pelapor adanya dugaan tindak pidana pencucian uang.

Jaminan perlindungan terhadap saksi dan korban memiliki peranan penting dalam proses peradilan pidana, sehingga dengan keterangan saksi dan korban yang diberikan secara bebas dari rasa takut dan ancaman dapat mengungkap suatu tindak pidana. Tidak terkecuali bagi notaris dalam kaitannya dengan permasalahan di atas yang seharusnya perlindungan hukum bagi notaris sebagai pihak pelapor juga dapat di atur lebih jelas guna menghindari adanya kekaburan hukum dalam pengaturan tentang kewajiban notaris di dalam UU Jabatan Notaris. Namun ternyata dalam Undang Undang Jabatan Notaris dan Undang-Undang Perlindungan Saksi dan Korban masih belum mengakomodir hal tersebut. Maka dalam penelitian fokus pembahasan adalah: Pertama, untuk menganalisis rasio legis ketentuan Pasal 3 Peraturan Pemerintah Nomor 43 Tahun 2015 terkait pelaporan indikasi tindak pidana pencucian uang yang berhubungan dengan rahasia jabatan Notaris. Kedua, ratio legis Pasal 16 ayat (1) huruf $F$ Undang-Undang Jabatan Notaris terkait wewajiban Notaris/PPAT merahasiakan akta dengan pengecualian. Ketiga, perlindungan hukum terhadap Notaris/PPAT sebagai pihak pelapor yang mengindikasi adanya tindak pidana pencucian uang.

\section{B. METODE PENELITIAN}

Jenis Jenis penelitian yang dipergunakan oleh peneliti adalah yuridis normatif, yaitu suatu proses untuk menemukan suatu aturan hukum, prinsip hukum, maupun doktrin-doktrin hukum untuk menjawab permasalahan hukum yang dihadapi dan dilakukan untuk menghasilkan argumentasi, teori atau konsep baru sebagai preskripsi dalam menyelesaikan masalah yang dihadapi.

Dalam penelitian yuridis normatif ini peneliti menggunakan beberapa macam metode pendekatan penelitian, diantaranya adalah Pendekatan perundang-undangan (statute approach), pendekatan konsep (conceptual approach). Untuk penelitian ini interpretasi yang digunakan diantaranya adalah interpretasi historis.

\section{PEMBAHASAN}

1. Rasio Legis Ketentuan Pasal 3 Peraturan Pemerintah Nomor 43 Tahun 2015 Terkait Pelaporan Indikasi Tindak Pidana Pencucian Uang Yang Berhubungan Dengan Rahasia Jabatan Notaris

Notaris sebagai pejabat umum, merupakan salah satu organ Negara yang dilengkapi dengan kewenangan hukum untuk memberikan pelayanan umum kepada masyarakat, teristimewa 
dalam pembuatan akta otentik sebagai alat bukti yang sempurna berkenaan dengan perbuatan hukum di bidang keperdataan. ${ }^{2}$

Wewenang Notaris salah satunya yakni membuat akta otentik dalam hal perbuatan hukum seseorang, akta otentik sengaja dibuat untuk dijadikan sebagai alat bukti tertulis dikemudian hari. Akta otentik harus sesuai dengan peristiwa yang terjadi, klien akan.memberikan kelengkapan berkas dan keterangan kepada Notaris, dari dua hal tersebut nantinya akan Notaris tuangkan ke dalam akta otentik. Suatu akta memiliki kekuatan bukti otentik, maka haruslah ada kewenangan dari pejabat umum yang membuat, dalam hal ini Notaris, untuk membuat akta otentik yang bersumber dari Undang-Undang. Dalam menjalankan tugas jabatannya Notaris membuat akta otentik dengan cara menformulasikan keinginan para pihak (klien) yang dituangkan ke dalam akta otentik, sehingga ketika klien memberi berkas maupun informasi harus sesuai dengan kenyataan, karena akan ada akibat hukum dikemudian hari mengenai keterangan para pihak yang disampaikan kepada Notaris. Notaris juga harus melihat apakah berkas itu asli atau tidak yang memungkinkan berkas itu dipalsu oleh klien demi kelancaran pembuatan akta otentik. Sesuai Peraturan Menteri Hukum Dan Hak Asasi Manusia Republik Indonesia Nomor 9 Tahun 2017 Tentang Penerapan Prinsip Mengenali Pengguna Jasa Bagi Notaris (PMPJ), untuk pencegahan dan pemberantasan tindak pidana pencucian uang, prinsip mengenali pengguna jasa wajib diterapkan oleh Notaris. Menurut Pasal 4 ayat (1) Permenkumham Nomor 9 Tahun 2017 menyebutkan bahwa dalam menerapkan prinsip mengenali pengguna jasa, Notaris wajib:

a. Memiliki kebijakan dan prosedur untuk mengelola dan memitigasi risiko pencucian uang dan/atau pendanaan terorisme yang diidentifikasi sesuai dengan penilaian risiko; dan

b. Melakukan penilaian risiko dan mengelompokkan Pengguna Jasa berdasarkan tingkat risiko terjadinya tindak pidana pencucian uang dan tindak pidana pendanaan terorisme.

Dengan adanya menejemen mengenali pengguna jasa orang perseorangan yang bersumber dari profil, karakteristik, bisnis, Negara, produk diharapkan Notaris dapat mengetahui dari mana sumber dana didapat, namun hal lain yang menyelimuti Notaris yang berkaitan dengan keterangan klien adalah rahasia menjaga kepentingan para pihak sesuai dengan amanat Undang-Undang Jabatan Notaris Pasal 16 ayat (1) huruf F yang menegaskan bahwa dalam menjalankan jabatannya Notaris wajib merahasiakan segala sesuatu mengenai Akta yang dibuatnya dan segala keterangan yang diperoleh guna pembuatan Akta sesuai dengan sumpah/ janji jabatan, kecuali undang-undang menentukan lain.

Ketentuan mengenai kewajiban seorang Notaris untuk merahasiakan segala sesuatu yang terkait dengan isi dan keterangan mengenai akta yang dibuatnya, melahirkan ketentuan tentang hak ingkar (verschoningsplicht) seorang Notaris yang dapat diterapkan apabila seorang Notaris ketika diminta untuk menjadi saksi di persidangan dan atau tidak berbicara di persidangan berkaitan dengan permasalah hukum akta yang dibuat Notaris.

Dengan demikian Pasal 4 ayat (2) jo Pasal 16 ayat (1) hurufF Undang Undang Jabatan Notaris (Perubahan) mengatur secara jelas bahwa seorang Notaris dalam menjalankan profesinya diwajibkan menjaga seluruh informasi yang berhubungan dengan akta, baik informasi klien, keterangan yang disampaikan oleh klien, maupun hal-hal lain yang berkaitan dengan isi akta, terkecuali Undang-Undang menentukan lain.

Seiring dengan maraknya tindak pidana pencucian uang, maka Notaris diwajibkan teliti dalam menerima dan memeriksa berkas serta informasi yang diterima, ciri khas utama dari Tindak Pidana Pencucian Uang adalah kejahatan yang dilakukan secara ganda dengan bentuk Pencucian uang sebagai kejahatan yang bersifat Follow Up Crime (Kejahatan Lanjutan), sedangkan kejahatan asalnya disebut sebagai Predicate Deffense/Core Crime atau sebagai

${ }^{2}$ Habib Adjie.(2005). Undang-Undang Jabatan Notaris (UUJN) sebagai Unifikasi Hukum Pengaturan Notaris. Jakarta: Renvoi, No. 28, Th. III, hlm. 130

Perlindungan Hukum Terhadap Notaris ..... | Daniella Herera Yosifany Hutagalung 103 
unlawful activity yaitu kejahatan asal yang menghasilkan uang yang kemudian dilakukan proses pencucian.(Munir Fuady,2013:36)

Ketentuan Pasal 18 UU No 8 tahun 2010 disebutkan bahwa Pihak Pelapor wajib menerapkan prinsip mengenali Pengguna Jasa, Jo Pasal 8 PP 43 tahun 2015 Pihak Pelapor Dalam Pencegahan dan Pemberantasan TPPU yang menyatakan bahwa pihak pelapor wajib menyampaikan laporan Transaksi Keuangan Mencurigakan kepada PPATK untuk kepentingan atau untuk dan atas nama Pengguna Jasa, Prinsip Mengenali pengguna jasa yang harus dilakukan Notaris meliputi:

a. Identifikasi yaitu pengumpulan informasi dan dokume pengguna jasa;

b. Verifikasi yaitu meniliti informasi dan dokumen yang diberikan pengguna jasa dan melakukan pertemuan langsung pengguna jasa;

c. Pemantauan transaksi yaitu mengetahui kesesuaian transaksi yang dilakukan dengan profil pengguna jasa.

Sedangkan menurut Pasal 2 ayat (4) huruf A sampai dengan D Permenkumham Nomor 9 Tahun 2017 tentang Prinsip Mengenali Pengguna Jasa, kewajiban Notaris dalam menerapkan Prinisp Mengenali Pengguna Jasa, dilakukan pada saat:

a. Melakukan hubungan usaha dengan pengguna jasa;

b. Terdapat transaksi keuangan dengan mata uang rupiah dan atau mata uang asing yang nilainya paling sedikit atau setara dengan Rp. 100.000.000,- (seratus juta rupiah);

c. Terdapat transaksi keuangan yang terkait tindak pidana pencucian uang;

d. Notaris meragukan kebenaran informasi yang dilaporkan pengguna jasa.

Dari uraian diatas, dapat dilihat bahwa untuk melaksanakan ketentuan Pasal 17 ayat (2) Undang-Undang Nomor 8 Tahun 2010 tentang Pencegahan dan Pemberantasan Tindak Pidana Pencucian Uang (selanjutnya disebut sebagai UU Pencegahan dan Pemberantasan TPPU) Jo Pasal 3 PP 43 Tahun 2015, Pemerintah memasukkan Notaris sebagai pihak pelapor.

Notaris termasuk kedalam kategori pihak pelapor dalam adanya dugaan tindak pidana pencucian uang, sebagaimana disebutkan dalam Pasal 3 Peraturan Pemerintah Nomor 43 Tahun 2015 tentang Pihak Pelapor Dalam Pencegahan dan Pemberantasan Tindak Pidana Pencucian Uang (selanjutnya disebut sebagai PP Pihak Pelapor Dalam Pencegahan dan Pemberantasan TPPU) yang menyebutkan bahwa pihak pelapor selain sebagaimana dimaksud dalam Pasal 2 mencakup juga:
a. Advokat;
b. Notaris;
c. Pejabat Pembuat Akta Tanah;
d. Akuntan;
e. Akuntan Publik;
f. Perencana Keuangan.

Jo Pasal 4 yang menyebutkan bahwa sebagaimana dimaksud dalam Pasal 2 dan Pasal 3 wajib menerapkan prinsip mengenali pengguna Jasa.

Sejauh ini Notaris berkewajiban untuk mengenal lebih jauh profile, latar belakang pengguna jasa kemudian dapat melaporkan apabila ada kecurigaan terhadap klien terkait dengan transaksi keuangan mencurigakan yang mencolok yang berbeda dengan identitas sebenarnya, namun di lain sisi, Notaris seakan akan di bebani oleh pembuktian secara materiil oleh Peraturan Pemerintah Dalam Pencegahan dan Pemberantasan TPPU, yang mewajibkan Notaris mengenali hingga menggali identitas pengguna jasa secara rinci, sampai sejauh mana Notaris harus mengenali profile, latar Sbelakang klien, sumber dana, karena tidak disebutkan secara eksplisit dalam Undang-Undang Jabatan Notaris. 
Selanjutnya dengan tidak disebutkan secara jelas prosedur dan format pelaporan bagi Notaris sebagai pihak pelapor yang wajib menyampaikan laporan kepada Pusat Pelaporan dan Analisis Transaksi Keuangan (PPATK) terkait Transaksi Keuangan Mencurigakan maka membuat Notaris sulit untuk mengetahui sumber dana para pihak karena Notaris tidak mempunyai kewajiban dalam Undang-Undang Jabatan Notaris untuk mggali lebih dalam perihal tersebut.

Bahwa ketentuan dalam PP Pihak Pelapor dalam Pencegahan dan Pemberantasan TPPU khususnya Pasal 3 dapat mengancam profesi Notaris dalam menjalankan tugas jabatannya, wajib lapor terhadap perbuatan hukum yang dilakukan oleh pengguna jasa yang diduga terindikasi tindak pidana pencucian uang. Setiap Notaris wajib melakukan pelaporan terhadap berbagai macam akta yang dibuatnya, termasuk legalisasi dan waarmeking.

Disisi lain Notaris berkewajiban melaporkan dugaan Transaksi Keuangan Mencurigaan, disisi lain hal tersebut menjadi ancaman bagi profesinya. Namun ketika Notaris tidak melaporkan maka akan dikenakan ancaman pada Pasal 322 KUHP yang menyebutkan bahwa Barang siapa dengan sengaja membuka rahasia yang wajib disimpannya karena jabatan atau pencariannya, baik yang sekarang maupun yang dahulu, diancam dengan pidana penjara paling lama sembilan bulan atau pidana denda paling banyak sembilan ribu rupiah.

\section{Ratio Legis Pasal 16 ayat (1) Huruf F Undang-Undang Jabatan Notaris Terkait Kewa- jiban Notaris/PPAT Merahasiakan Akta dengan Pengecualian}

Usaha-Ketentuan mengenai kewajiban Notaris merahasiakan akta tertuang padal Pasal 16 ayat (1) hurufF Undang Undang Jabatan Notaris yang menyebutkan bahwa dalam menjalankan jabatan Notaris wajib merahasiakan segala sesuatu mengenai Akta yang dibuatnya dan segala keterangan yang diperoleh guna pembuatan Akta sesuai dengan sumpah/janji jabatan, kecuali undang-undang menentukan lain.

Sedangkan Kode Etik PPAT ada dalam peraturan lebih lanjut yaitu Pasal 28 ayat (2) huruf c Peraturan Kepala Badan Pertanahan Nasional No. 1 Tahun 2006 tentang Ketentuan Pelaksanaan PP No. 37 Tahun 1998 tentang Peraturan Jabatan Pejabat Pembuat Akta Tanah. Yang berwenang mengangkat dan memberhentikan dengan tidak hormat dari jabatan PPAT jika melanggar kode etik profesi yang berkaitan dengan rahasia jabatan adalah Kepala Badan Pertanahan Nasional. Kode etik profesi PPAT disusun oleh Organisasi PPAT dan/atau PPAT Sementara dan ditetapkan oleh Kepala BPN yang berlaku secara nasional (Pasal 69 Perka BPN 1/2006). Organisasi PPAT yang dimaksud saat ini adalah Ikatan Pejabat Pembuat Akta Tanah (IPPAT)

Artinya Notaris/PPAT dalam menjalankan jabatan kepercayaan maka Notaris wajib menjaga rahasia akta demi kelancaran pembuatan akta dan kepentingan para pihak serta sebagai bentuk tanggung jawab Notaris dalam menjalankan jabatan yang dimaksud dengan jabatan kepercayaan adalah Notaris sebagai pejabat publik mengemban amanah dan kepercayaan masyarakat yang harus dijalankan dengan hati-hati dan sebaik-baiknya, kemudian dalam Pasal 16 Undang-Undang Jabatan Notaris juga menegaskan pengecualian terhadap rahasia jabatan yakni frasa "kecuali Undang-Undang menentukan lain" yang artinya ketika ada UndangUndang lain memuat ketentuan terkait membuka rahasia jabatan, maka Notaris harus tunduk pada hukum yang berlaku.

Sumpah jabatan Notaris/PPAT maupun kode etik Notaris/PPAT keduanya memuat tentang rahasia jabatan yang dimiliki oleh Notaris. Notaris sebagai jabatan kepercayaan wajib untuk menjaga rahasia yang dipercayakan orang yang menggunakan jasa Notaris kepadanya. Hubungan profesi notaris dengan organisasi diatur dalam kode etik notaris (KEN). KEN memuat unsur kewajiban, larangan, pengecualian dan sanksi yang akan dijatuhkan apabila 
notaris melakukan pelanggaran terhadap kode etik. Selain itu kode etik juga mengatur tata cara penegakkan kode etik dan pemecatan sementara sebagai anggota INI.

Rahasia jabatan tidak sekedar merupakan ketentuan etik melainkan menjadi asas hukum yang diberikanverschoningsrecht. ${ }^{3}$

Mahkamah Agung telah mengeluarkan surat keterangan Nomor MA/Pemb/3425/86 tanggal 12 April 1986 yang mengatur antara lain:

a.Notaris yang akan diperiksa atau dimintai keterangan harus jelas kedudukan dan perannya, apakah sebagai saksi atau tersangka terhadap akta-akta yang dibuatnya dan/atau selaku pemegang protokol;

b.Dalam kedudukan dan perannya sebagai saksi, maka pemeriksaaan tidak perlu dilakukan peyumpahan, kecuali ada cukup kuat alasan, bahwa ia tidak dapat hadir dalam pemeriksaan di sidang pengadilan sebagaimana diatur dalam Pasal 116 ayat (1) KUHAP. Sanksi terhadap Notaris yang membuka rahasia jabatannya dengan mengabaikan hak ingkar yang melekat padanya dapat dikenai sanksi:

1. Sanksi pidana: melanggar Pasal 322 ayat (1) KUHP

2. Sanksi Perdata: Pasal 1365 KUHPerdata

3. Sanksi administrati: Pasal 16 ayat (11) dan ayat (12)

4. Sanksi kode etik Notaris

Apabila pemanggilan dan pemeriksaan Notaris oleh penyidik kepolisian tidak mengindahkan prosedur hukum yang berlaku, maka dikhawatirkan akan terjadi kesewenang-wenangan dan menimbulkan ketidakpastian hukum. Segala upaya yang menjamin adanya kepastian hukum adalah benteng untuk menghalangi kesewenang-wenangan. ${ }^{4}$

Notaris dapat berperan sebagai saksi dalam proses peradilan, peranan Notaris sebagai saksi pada proses peradilan erat kaitannya dengan substansi sumpah jabatanitu sendiri. Disatu sisi dengan adanya sumpah jabatan Notaris yang didalamnya terkandung rahasia jabatan mengharuskan Notaris untuk tidak memberi keterangan apapun mengenai akta, disisi lain pada kenyataannya ketentuan rahasia jabatan dan hak ingkar ini diterobos dengan danya kepentingan negara yang lebih tinggi dan besar serta adanya ketentuan eksepsional, sehingga Notaris dalam berperan dalam proses peradilan. Berangkat dari pembahasan mengenai prinsip mengenal pengguna jasa, tidak ada ruginya bagi Notaris/PPAT untuk lebih hati-hati kedepannya dalam melakukan transaksi dengan penghadapnya dalam upaya melakukan pencegahan dalam Tindak Pidana Pencucian Uang berdasarkan Undang-Undang Tindak Pidana Pencucian Uang (TPPU) Nomor 8 Tahun 2010, dan untuk itu ada beberapa hal yang perlu dilakukan oleh Notaris, yaitu: 5

1. Kegiatan mengenali pengguna jasa yaitu sesuai Undang-Undang No.8 Tahun 2010 tentang Pencegahan dan Pemberantasan Tindak Pidana Pencucian Uang (TPPU) terdapat beberapa pengaturan mengenai kewajiban Pengguna jasa seperti memberikan identitas dan informasi yang benar, sumber dana, dan tujuan transasksi pihak lain tersebut.

2. Pengelolaan resiko yaitu Penerapan Prinsip Mengenali Pengguna Jasa (PMPJ) atau penerapan Program Prinsip Mengenal Nasabah dan Anti Pencucian Uang (APU PPT), merupakan bagian penting bagi manajemen risiko yang baik, terutama dalam pengelolaan risiko reputasi, risiko operasi, risiko hukum dan risiko konsentrasi, yang satu dengan lainnya saling berhubungan. Dalam hal pengenalantingkatresiko, hendaknya perludilakukanpengelompokkandan analisis terhadap identitas penghadap, profil penghadap, jumlah transaksi, kegiatan usaha penghadap dan informasi lainnya yang dapat digunakan untuk mengukur resiko penghadap.

\footnotetext{
${ }^{3}$ Pingkan Sundah, Tinjauan Yuridis Terhadap Tidak Dilaksanakannya Kewajiban Jabatan Notaris Menurut Undang-Undang Nomor 2 Tahun 2014, Jurnal: ejournal.unsrat.ac.id, hlm. 37

${ }^{4}$ Satjipto Rahardjo.(2004). Hukum dan Masyarakat. Bandung: Angkasa, hlm. 102

${ }^{5}$ Djoko Sukisno.(2004). Peranan Notaris Sebagai Saksi Dalam Proses Peradilan Serta Kaitannya dengan Sumpah Jabatan Notaris, Jurnal: edt.repository.ugm.ac.id., hlm. 127
} 
Jadi Rasio legis kewajiban Notaris/PPAT sebagai pihak pelapor dalam adanya dugaan tindak pidana pencucian uang (TPPU) bertujuan untuk melindungi para pengemban profesi yang luhur ini. Indonesia adalah Negara hukum yang berdasarkan Pancasila, dimana setiap warganya dituntut untuk turut berperan serta dalam menegakkan hukum, keadilan dan kebenaran, bahwa untuk mencapai tujuan tersebut setiap Notaris/PPAT sebagai pengabdi dituntut untuk memiliki tekad dalam menegakkan hukum, keadilan dan kebenaran sebagai wujud dari rasa tanggung jawab kepada negara, sebagai pejabat umum Notaris/PPAT menegakkan hukum sesuai dengan profesinya dengan menyumbangkan tenaga dan pikiran serta menjalankan tugas jabatan dengan amanah, jujur, mandi dan tidak berpihak.

Adanya Pasal 3 PP Nomor 43 Tahun 2015 tentang Pihak Pelapor Dalam Pencegahan Dan Pemberantasan Tindak Pidana Pencucian Uang yang memasukkan Notaris/PPAT dalam kategori pelapor berupaya sebagai bentuk pencegahan penyalahgunaan terhadap oknum yang tidak bertanggung jawab terhadap profesi mulia ini.

Namun PP No. 43 Tahun 2015 tidak memberikan patokan yang cukup jelas dan payung hukum aman bagi Notaris maupun PPAT terkait transaksi keuangan yang mencurigakan seperti apa yang mewajibkan Notaris/PPAT membuat laporan untuk melapor ke Pusat Pelaporan dan Analisis Transaksi Keuangan (PPATK), karena tujuan Notaris/PPAT dalam pengabdian kepada masyarakat yakni untuk menjunjung tinggi kebenaran dan keadilan serta mengupayakan terwujudnya kepastian hukum.

Padahal laporan tersebut berkaitan dengan besaran nilai transaksi. Peraturan Pemerintah Nomor 43 Tahun 2015 telah mengecualikan kerahasiaan yang harus dijaga Notaris terkait informasi yang diperoleh dari pengguna jasa dalam menjalankan tugas jabatannya. Ditegaskan dalam Undang-Undang Jabatan Notaris :

"dalam menjalankan jabatannya Notaris wajib merahasiakan segala sesuatu mengenai Akta yang dibuatnya dan segala keterangan yang diperoleh guna pembuatan Akta sesuai dengan sumpah/janji jabatan, kecuali undang-undang menentukan lain”.

Bahwa aturan diatas jelas menegaskan terkait rahasia jabatan Notaris dapat diberikan sebagai bentuk kesaksian atau keterangan apabila Undang-Undang menentukan lain, akan tetapi ketentuan yang berlaku mengenai Notaris yang wajib membuka rahasia jabatan bukan sebagai Undang-Undang melainkan Peraturan Pemerintah. Jadi kesimpulan yang terdapat dalam permasalahan Notaris/PPAT sebagai pihak pelapor dalam dugaan tindak pidana pencucian uang adalah belum adanya payung hukum berupa Undang-Undang yang jelas untuk melindungi pelaksana jabatan, sebagaimana telah diuraikan dalam Undang-Undang Jabatan Notaris, oleh sebab itu seharusnya pemerintah khususnya Kementerian Hukum dan HAM dan Badan Pertanahan Nasional membuat peraturan perundang undang guna mencapai kepastian hukum terkait perlindungan hukum bagi Notaris/PPAT, selanjutnya pelaksana jabatan dapat mengetahui dengan jelas aturan dan mekanismenya sehingga tidak merugikan bagi Notaris/ PPAT yang bersangkutan dan bagi organisasi sendiri.

\section{Perlindungan Hukum Terhadap Notaris/PPAT Sebagai Pihak Pelapor Yang Mengindi- kasi Adanya Tindak Pidana Pencucian Uang}

Upaya perlindungan preventif (pencegahan) adanya tindak pidana pencucian uang dapat dilakukan oleh Notaris/PPAT dengan cara menerapkan prinsip kehati-hatian kepada pengguna jasa dalam menjalankan tugas jabatannya. Sehingga dengan adanya akibat hukum dikemudian hari, Notaris/PPAT dapat bertanggung jawab secara pidana maupun perdata. Hal ini dapat diterapkan oleh Notaris/PPAT dalam menjalankan tugas jabatannya dengan cara memeriksa secara teliti berkas dan profile pengguna jasa agar dapat mengetahui sejak dini bila ada dugaan 
adanya tindak pidana pencucian uang, permasalahannya yang timbul terkait pemberkasan yang diterima oleh Notaris/PPAT yakni adanya berkas dan keterangan palsu yang disampaikan oleh pengguna jasa, sehingga Notaris/PPAT yang tidak cermat akan dengan mudah dikelabuhi oleh pelaku pencucian uang. Notaris mempunyai peranan untuk menentukan suatu tindakan dapat dituangkan dalm bentuk akta atau tidak. Sebelum sampai pada keputusan seperti ini, Notaris harus mempertimbangkan dan melihat semua dokumen yang dilakukan saat pemberkasan, meneliti semua bukti yang diperlihatkan padanya, mendengarkan keterangan atau pernyataan para pihak. Keputusan tersebut harus didasarkan pada alasan hukum yang harus dijelaskan kepada para pihak. Pertimbangan tersbut harus memperhatikan seluruh aspek hukum termasuk masalah hukum yang akan timbul dikemudian hari. Selain itu setiap akta yang dibuat dihadapan atau oleh Notaris harus mempunyai alasan dan fakta yang mendukung untuk akta yang bersangkutan atau ada pertimbangan hukum yang harus dijelaskan kepada para pihak/penghadap. Notaris dalam menjalankan tugas jabatannya harus tetap pada koridor yang ditentukan dan Undang-Undang Jabatan Notaris dan Kode Etik Jabatan Notaris.

\section{KESIMPULAN}

Berdasarkan pembahasan tersebut di atas dapat disimpulkan beberapa hal, yaitu:

Rasio legis pengaturan Notaris dan PPAT tidak disertai dengan ketentuan perlindungan hukum sebagai pihak pelapor dalam Tindak pidana pencucian uang dirasa dirasa kurang tepat, karena demi menjamin perlindungan hukum bagi pihak pelapor maka diperlukan kepastian hukum demi menjaga keamanan dan kelancaran ketika menyampaikan pelaporan, pun juga demikian dengan Peraturan Pemerintah Nomor 43 Tahun 2015 tentang Pihak Pelapor dalam Pencegahan dan Pemberantasan Tindak Pidana Pencucian Uang Jo Permenkumham Nomor 9 Tahun 2017 tentang Penerapan prinsip mengenali pengguna jasa bagi Notaris, bahwa sesungguhnya Notaris tidak berkewajiban untuk menggali kebenaran materiil kepada para pengguna jasa, namun yang berwenang untuk hal tersebut adalah hakim di pengadilan.

Upaya perlindungan hukum bagi Notaris oleh Majelis Kehormatan Notaris berupa pengawasan dan pemberian sanksi serta sebagai gerda depan Notaris ketika berurusan dengan pihak berwenang baik kepolisian maupun kejaksaan, Notaris tidak dapat sewenang-wenang dipanggil oleh penyidik karena penyidik harus melalui beberapa tahapan untuk menghadirkan Notaris sebagai saksi untuk dimintai keterangan, adapun prosedur yang wajib dilakukan oleh pihak berwenang dengan car mengirimkan surat permohonan pemanggilan Notaris kepada Majelis Kehormatan Notaris.

\section{Daftar Pustaka}

\section{Buku}

Tan Thong Kie.(2000). Studi Serba Serbi Praktek Notaris. Jakarta: IchtiarBaru Van Hoeve.

Satjipto Rahardjo.(2004). Hukum dan Masyarakat. Bandung: Angkasa.

Djoko Sukisno.(2004). Peranan Notaris Sebagai Saksi Dalam Proses Peradilan Serta Kaitannya dengan Sumpah Jabatan Notaris, Jurnal: edt.repository.ugm.ac.id.

Habib Adjie.(2005). Undang-Undang Jabatan Notaris (UUJN) sebagai Unifikasi Hukum Pengaturan Notaris. Jakarta: Renvoi, No. 28, Th. III.

\section{Jurnal}

PingkanSundah.(2014). Tinjauan Yuridis Terhadap Tidak Dilaksanakannya Kewajiban Jabatan 
Notaris Menurut Undang-Undang Nomor 2 Tahun, Jurnal: ejournal.unsrat.ac.id.

\section{Undang-Undang}

Indische Kitab Undang Undang Hukum Perdata Burgerlijk Wetboek (BW)

Undang-Undang Nomor 30 Tahun 2004 tentang Jabatan Notaris

Undang-Undang Nomo 8 Tahun 2010 tentang Pencegahan Tindak Pidana Pencucian Uang

Undang-undang Nomor 2 Tahun 2014 tentang Perubahan atas Undang-Undang Nomor 30 Tahun 2004 tentang Jabatan Notaris

Peraturan Pemerintah Republik Indonesia Nomor 57 Tahun 2003 tentang Tata Cara Perlindungan Khusus Bagi Pelpaor dan Saksi Tindak Pidana Pencucian Uang

Peraturan Pemerintah Nomor 43 Tahun 2015 tentang Pihak Pelapor dalam Pencegahan dan Pemberantasan Tindak Pidana Pencucian Uang

Peraturan Menteri Hukum Dan Hak Asasi Manusia Republik Indonesia Nomor 9 Tahun 2017 Tentang Penerapan Prinsip Mengenali Pengguna Jasa Bagi NotarisKitab Undangundang Hukum Perdata (KUHPerdata)/ Burgerlijk Wetboek voor Indonesie (BW) 